\title{
ROLA I ZNACZENIE MIAST W BUNTACH PRZECIW OTTONOWII
}

\begin{abstract}
Streszczenie. W trakcie swego panowania Otton I musiał stawić czoła trzem poważnym buntom przeciw jego władzy, to jest swych braci Thankmara i Henryka oraz swego syna Liudolfa. Celem niniejszej pracy jest przedstawienie roli i znaczenia miast w tych wystąpieniach na podstawie analizy źródeł głównie o charakterze narracyjnym. W wyniku przeprowadzonego postępowania badawczego można stwierdzić, że znaczenie wszelkiego rodzaju umocnionych placówek było bardzo duże, ponieważ umożliwiały one znaczne umocnienie się w regionie. Odnośnie do Thankmara taka rola przypadła Eresburgowi i Laër, którego kapitulacja oznaczała nawet faktyczny koniec rebelii. Nie inaczej było w pozostałych wypadkach, kiedy to w powstaniu Henryka walki koncentrowały się wokół Merseburga, Chevermont i Scheidungen, a dla Liudolfa centralnym punktem oporu stała się ostatecznie Ratyzbona. W tym ostatnim wystąpieniu znacząca rola przypadła także takim ośrodkom jak Moguncja, Kolonia, Augsburg i Schwabmünchen w Szwabii.
\end{abstract}

Słowa kluczowe: Otton I, Thankmar, Henryk, Liudolf, Eresburg, Laër, Merseburg, Chevermont, Scheidungen, Ratyzbona, Augsburg, Schwabmünchen

Pierwszą część panowania Ottona I charakteryzowały gwałtowne bunty przeciw jego władzy, czego powód widzi się głównie w zmianie stylu rządów tego władcy w porównaniu z rządami jego ojca. Najogólniej mówiąc - podczas gdy Henryk I nie wahał się nawiązywać stosunków przyjaźni z innymi królami, a także z własnymi lennikami, i to nie tylko z książętami, lecz również z przedstawicielami Kościoła i potężniejszymi hrabiami, dzięki czemu jako pierwszy pośród równych zdobył szerokie uznanie dla własnych rządów, to jego syn nie zamierzał już zawierać ze swymi poddanymi układów na zasadzie równości, co zamanifestował, m.in. mianując w 936 r. Hermana Billunga następcą po legacie Bernardzie i w 937 r. Gerona po zmarlym Zygfrydzie. W tym okresie 
sytuację Ottona I po śmierci Henryka I komplikowała dodatkowo kwestia wyposażenia i pozycji jego braci Thankmara i Henryka, a nieco później również własnego syna Liudolfa ${ }^{1}$.

Do waśni wewnątrz państwa doszło bardzo szybko po koronacji królewskiej Ottona I, bo już w 937 r. Jak zapisał tak zwany Kontynuator Reginona z Prüm, w tymże roku doszło do wielkiej niezgody między Henrykiem, bratem króla, a Eberhardem, księciem Franków, z powodu sporów między ich wasalami². O wydarzeniach tych wspomniał także Widukind, ale jego zdaniem powodem konfliktu była przepełniająca Sasów duma z racji posiadania króla z własnego kręgu, tak że uważali za niegodne służyć innym plemionom oraz wzdragali się zawdzięczać lenna komuś innemu niż królowi³ . Odnośnie do motywu konfliktu podanego przez Widukinda, to jest sasko-frankijskiego antagonizmu, wyrażono w literaturze przedmiotu poważne wątpliwości. Po pierwsze, zauważono, że termin quaestura użyty przez kronikarza był synonimem officium, czyli swego rodzaju urzędu, który można było otrzymać tylko dzięki łasce królewskiej i który niewątpliwie przysługiwał Eberhardowi do końca panowania Henryka I. Wraz ze zmianą na tronie, jak zaznaczono powyżej, doszło do zmiany w pojmowaniu i sprawowaniu rządów, co tłumaczy, że dopiero teraz Sasi zgłosili pretensje do bezpośredniej zależności od króla ${ }^{4}$. Po drugie, po wyznaczeniu przez Henryka I tylko jednego następcy wytworzyła się w rodzinie Liudolfingów sytuacja niepozostająca bez wpływu na dotychczasową pozycję Eberharda jako dux regni czy secundus a rege, usiłującego zapewne tak jak Otton I w całym tym sporze rozbudować swe pozycje władcze ponad granice szczepowe w regnum Francorum et Saxonum w celu zachowania swej dotychczasowej roli' W tym kontekście podkreślić jeszcze warto, że wbrew zapatrywaniom wcześniejszej literatury Ottonowi I początkowo udało się porozumieć ze swym bratem Henrykiem za cenę

1 Vide: G. Althoff, Die Ottonen. Königsherrschaft ohne Staat, Stuttgart-Berlin-Köln 2000, s. 69 i n.; H. Beumann, Die Ottonen, Stuttgart-Berlin-Köln 2000, s. 58 i n.; J. SoCHacki, Formowanie sie wczesnośredniowiecznego państwa niemieckiego w latach 919-962, Słupsk 2014, s. 218 i n.; IDEM, Początki państw. Niemcy, Poznań 2016, s. 92 i n.; J. STrzelczyK, Otton I Wielki, Poznań 2018, s. 78 i n.

2 Continuator Reginonis Trevirensis, MGH SS I, ed. G.H. PerTZ, Stuttgart 1976, s. 617.

3 Widukindimonachi Corbeiensis rerum gestarum Saxonicarum libritres, ScRG LX, ed. P. HIRSCH, Hannover 1935, II, 6, s. 71.

${ }^{4}$ T. ZoTZ, Amicitia und Discordia. Zu einer Neuerscheinung über das Verhältnis von Königtum und Adel im frühottonischer Zeit, „Francia” 1989, R. 1, s. 173 i n.

5 M. BECHER, Rex, dux und gens. Untersuchungen zur Entstehung des sächsischen Herzogtums im 9. Und 10. Jabrhundert, Paderborn 1996, s. 239 i n. 
uczynienia z niego w państwie drugiej osoby po królu ${ }^{6}$. Zapewne ten właśnie fakt był tłem walk w 937 r. między Henrykiem a Eberhardem.

Według relacji Widukinda pierwszy do działań zbrojnych przystąpił książę frankoński, atakując Helmern w Hassegau, gród należący do niejakiego Bruninga. O znaczeniu tego ośrodka trudno jest cokolwiek powiedzieć, ale wydaje się, że w tym wypadku nie chodziło o względy natury strategicznej. Widukind zaznaczył przecież nieco wcześniej niechęć Sasów do zawdzięczania lenn komuś innemu niż Ottonowi I, zatem wystąpienie Eberharda przeciwko Bruningowi należy ocenić jako atak na niewiernego wasala i stąd też zapewne surowe potraktowanie tej miejscowości - spalenie zabudowań i wymordowanie mieszkańców. Za ten czyn król nakazał księciu frankońskiemu dostarczyć koni o łącznej wartości stu talentów, a jego wodzom nieść psy aż do Magdeburga7. Mimo pojednawczych gestów Ottona I wobec frankońskiego możnowładztwa w tym grodzie $^{8}$ spór między Eberhardem a Bruningiem trwał nadal. Z dostępnych źródeł nic nie wiadomo o zdobywaniu jakichś ośrodków miejskich, być może dlatego, że były one za małe, a tym samym niezbyt znaczące, w każdym razie walki prowadzono w sposób wyjątkowo okrutny, dopuszczając się wszędzie zniszczeń i podpaleń9.

Otton I wciąż usiłował rozwiązać ten spór na drodze pokojowej, zwołując w maju 938 r. zgromadzenie w Steele, gdzie wybaczono wszystkim zakłócającym pokój ich winy, mimo że ci się nie stawili ${ }^{10}$. Taka postawa Eberharda i jego zwolenników wynikała zapewne z opowiedzenia się po ich stronie przyrodniego brata Ottona I Thankmara. Jak już wspomniano, Otton I zdecydował się po śmierci Zygfryda (3 grudnia 937 r.) ${ }^{11}$ powierzyć jego funkcję Geronowi, bratu zmarłego, ale pretensje do tego urzędu zgłaszał również Thankmar, co według Widukinda motywował swym pokrewieństwem z Zygfrydem,

${ }^{6}$ Świadczą o tym przekazy: Hrotsvitha, Gesta Ottonis, [w:] Hrotsvithae opera, ScRG XXXIV, ed. P. von Winterfeld, Berlin 1902, v. 153 i n.; Flodoardi annales, MGH SS III, ed. G.H. PerTZ, Hannover 1839, s. 383; LiUtprand, Antapodosis, [w:] Liutprandi opera, ScRG XLI, ed. J. BeCKer, Hannover-Leipzig 1915, IV, 20, s. 115. Vide: M. BeCHER, Otton Wielki. Cesarz i państwo, przekł. B. LipKA, Oświęcim 2020, s. 92.

7 Widukindi..., II, 6, s. 71 i n.

8 Ibidem, II, 7, s. 72.

9 Ibidem, II, 10, s. 73.

${ }_{10}$ Ibidem, II, 10, s. 74.

${ }_{11}$ Vide: Ch. LÜBKE, Regesten zur Geschichte der Slaven an Elbe und Oder (vom Jahr 900 an), t. 2, Berlin 1985, s. 81. 
aczkolwiek tylko kognatycznej natury ${ }^{12}$. O wiele bardziej prawdopodobne wydaje się jednak, że swe prawa uzasadniał posiadaniem wyższej rangi w obrębie rodu Zygfryda, jako syn Henryka I, oraz posiadaniem po matce dziedzicznych praw do Merseburga ${ }^{13}$.

Thankmar i Eberhard przystąpili do działań szybko i zdecydowanie, atakując i zdobywając Belecke ${ }^{14}$. Najpewniej znaczenie tego grodu polegało na tym, że przebywał tam Henryk, którego chciano pojmać w niewolę, co też się udało ${ }^{15}$. Do zdobycia Belecke doszło z zaskoczenia w nocy przy dokonaniu licznych podpaleń $^{16}$, natomiast sam gród został wydany na pastwę rabunków ${ }^{17}$. Widukind pisze, że łupy były tak obfite, iż jego żołnierze byli teraz gotowi do wszelkich czynów $^{18}$. Jedynym, ale za to bardzo niekorzystnym wydarzeniem w trakcie toczonych walk, było zabicie przez zdobywców bratanka księcia szwabskiego Gebharda, przez co doszło do rozłamu w rodzie Konradynów, a to fatalnie wpłynęło na pozycję Eberharda ${ }^{19}$.

Następnym posunięciem Thankmara było zajęcie Eresburga, zapewne ważnego dla niego ośrodka, skoro tam osiadł i stamtąd dokonywał wielu rabunków. Doszło do tego w bliżej nieokreślonych okolicznościach, ale można domniemywać, że miejscowy garnizon był mu przyjazny, skoro armia Ottona I wracała wzbogacona wziętymi tam łupami. Ten ostatni fakt może nieco zaskakiwać, ponieważ mieszkańcy tego grodu postanowili poniechać oporu i otworzyli królowi

12 Widukindi..., II, 9, s. 73.

13 H. KELLER, Reichsstruktur und Herrschaftsauffassung in ottonisch-frühsalischer Zeit, „Frühmittelalterliche Studien” 1982, R. 16, s. 112; K.J. LEYSER, Herrschaft und Konflikt. König und Adel im ottonischen Sachsen, Göttingen 1984, s. 26 i n. O tym, że Thankmara do buntu przeciw bratu skłoniło również pozbawienie go dóbr po matce, vide: Widukindi..., II, 11, s. 76.

14 Belecke zdobył tylko Thankmar, choć o samym Eberhardzie mówią np. LIUTPRAND (IV, 20, s. 115) i Cont. Reg. (s. 617; pod rokiem 938).

15 Za tym, że Henryk miał odgrywać rolę zakładnika, świadczą przekazy Hrotsvithy (v. 183-185), Liutpranda (IV, 20, s. 115) i Widukinda (II, 11, s. 75), mówiące o jego niegodnym traktowaniu jako jeńca oraz jeszcze ten ostatni (II, 11, s. 78) piszący o rzuceniu się Eberharda do stóp Henryka i błaganiu o przebaczenie, gdy uznał swą sprawę za przegraną.

16 Hrotsvitha, v. 182.

17 O zdobyciu przez Thankmara bogatych skarbów piszą HROTSVITHA (v. 186) oraz LiUTPRAND (IV, 20, s. 115).

18 Widukindi..., II, 11, s. 74 i n. Że czyny te nie były zgodne z nakazami honoru, vide dalszy ciąg tej notki na s. 75 .

19 Widukindi..., II, 11, s. 75. Natomiast LiUTPRAND (IV, 23, s. 116) pisze o przejściu na stronę Ottona I księcia Hermana ze Szwabii i jego braci Udona oraz Konrada. 
bramy miasta. W tej sytuacji Thankmar widział jedyne wyjście w ucieczce do kościoła, gdzie stanął obok ołtarza, na którym złożył swą broń i złoty łańcuch ${ }^{20}$. Niewiele mu to pomogło, bo zawzięcie ścigany, zwłaszcza przez ludzi Henryka, którzy pragnęli pomścić zadaną ich panu hańbę i z tego względu nie wahali się wyważyć drzwi do kościoła, został zabity pchnięciem oszczepu przez niejakiego Mainicię (28 lipca 938 r.). Otton I, niezadowolony z powodu zabicia swego brata, nie ukarał jednak sprawców tego czynu, ponieważ ze względu na trwającą wojnę domową nie chciał burzyć dobrych nastrojów w armii. Jednakże Tiadryka i trzech synów jego ciotki, sprzyjających Thankmarowi, skazał zgodnie $z$ frankijskim obyczajem na powieszenie, a następnie pomaszerował na Laër ${ }^{21}$, położone na zachód od Meschede ${ }^{22}$.

Nieco wcześniej, gdy Thankmar zdobył Eresburg, doszło pod bramami Laër do zabicia niejakiego Dedi, co tak poruszyło Wichmana Starszego, że porzucił spiskowców i przeszedł na stronę Ottona $\mathrm{I}^{23}$. Gród ten był obsadzony przez ludzi księcia Eberharda i dlatego też zapewne doszło teraz do regularnego oblężenia, przy którym odznaczył się szczególnie podczaszy królewski Tamma. Zamknięci w twierdzy nie widzieli jednak szans powodzenia dalszego oporu i dlatego poprosili Ottona I o rozejm, by nawiązać kontakt ze swoim księciem. Mimo otrzymania zgody na zawieszenie broni Eberhard nie zdecydował się na udzielenie wsparcia swoim ludziom, więc ci postanowili, co zapewne było warunkiem rozejmu, wyjść z grodu i poddać się władzy króla. Upadek Laër dopełnił miary niepowodzeń Eberharda ${ }^{24}$, tak że postanowił on najpierw prosić o przebaczenie przebywającego u niego Henryka ${ }^{25}$, a następnie za pośrednictwem arcybiskupa mogunckiego Fryderyka udał się do Ottona I, zdając się wraz ze swoimi ludźmi i majątkiem na jego wyrok. Skazany początkowo

${ }^{20}$ O symbolicznym znaczeniu tego gestu vide: G. Althoff, H. Keller, Heinrich I. und Otto der Grosse. Neubeginn aufkarolingischem Erbe, Bd. 1, Göttingen-Zürich 1985, s. 140 i n.; W. GLOCKER, Die Verwandten der Ottonen und ihre Bedeutung in der Politik. Studien zur Familienpolitik und zur Genealogie des sächsischen Kaiserhauses, Köln-Wien 1989, s. 50; J. LAUDAGE, Otto der Grosse (912-973). Eine Biographie, Regensburg 2001, s. 73 i n.

21 Widukindi..., II, 11, s. 75 i n. O powieszeniu zwolenników Thankmara lub ich okaleczeniu wspomina także Cont. Reg. (s. 618; pod rokiem 939).

22 W grę wchodzi też zamek Laar na wschód od Arlosen.

23 Widukindi..., II, 11, s. 75.

24 Jak zaznacza J. LAUDAGE, op. cit., s. 115 - opanowanie Laër oznaczało, że Engern i Westfalia znalazły się ponownie w rękach Ottona I.

25 Widukindi..., II, 11, s. 77 i n. 
na wygnanie do Hildesheim zdołał jednak Eberhard rychło odzyskać łaskę królewską i przywrócenie do godności książęcej ${ }^{26}$.

W trakcie wystąpienia Thankmara i Eberharda doszło również do zaburzeń w Bawarii ${ }^{27}$. Zdaniem Widukinda po śmierci księcia Arnulfa w 937 r. jego synowie, z których Eberhard został następcą po ojcu ${ }^{28}$, mieli odmówić królowi złożenia należnego mu hołdu ${ }^{29}$. W nowszej historiografii pojawił się jednak pogląd, że kronikarz usiłował obarczyć winą za wybuchły konflikt Eberharda, dążącego tylko do utrzymania swej samodzielności ${ }^{30}$, przy czym nie zmierzał on raczej do sprowokowania działań wojennych w sposób opisany przez Widukinda $^{31}$. Jak by nie było, do pokonania synów Arnulfa doszło w 938 r., kiedy to Otton I osobiście poprowadził wyprawę do Bawarii. Niestety źródła poskąpiły informacji o przebiegu tej kampanii, zadowalając się tylko stwierdzeniem, że król podporządkował sobie wszystkich poza Arnulfem, synem zmarłego księcia bawarskiego, dotychczasowego księcia Eberharda skazał na wygnanie, a na jego miejsce osadził jego stryja Bertholda ${ }^{32}$. W tej sytuacji można jedynie domniemywać, że miasta czy grody nie odegrały żadnej poważniejszej roli podczas działań wojennych, nie tylko ze względu na milczenie źródeł na ten temat, ale również dlatego że kampania była szybka i zakończyła się niemal całkowitym

${ }^{26}$ Ibidem, II, 13, s. 78. O karach, jakie spotkały Eberharda, vide: Annales Augienses, MGH SS I, ed. G.H. PERTZ, Hannover 1826, s. 69 (pod rokiem 938); Annales Quedlinburgenses, MGH SS III, ed. G.H. Pertz, Hannover 1839, pod r. 937, s. 56; Cont. Reg., s. 617 (pod rokiem 938); Hrotsvitha, v. 200 i n. - ta ostatnia jako jedyna pisze o powieszeniu pewnych buntowników bądź wygnaniu ich z ojczyzny.

27 Źródła do działań wojennych Ottona I w Bawarii vide: K. ReIndeL, Die bayerischen Luitpoldinger 893-989. Sammlung und Erläuterung der Quellen, München 1953, nr 93, s. 183 i n.

28 Arnulf dokonał desygnacji swego syna Eberharda na następcę już w 935 r. - vide: Annales Iuvavenses maximi, MGH SS XXX, 2, ed. H. BRESSLAU, Leipzig 1934, s. 743 (pod rokiem 935).

29 Widukindi..., II, 8, s. 72. O buncie Eberharda bawarskiego mówi Cont. Reg., s. 617 i n. (pod rokiem 938), a ogólnie o buncie Bawarów Herimanni Augiensis chronicon, MGH SS V, ed. G.H. PERTZ, Hannover 1985, s. 113 (pod rokiem 937).

30 Szczególnym uprawnieniem Arnulfa było prawo obsadzania biskupstw bawarskich. Zwłaszcza na ten wątek wskazuje Thietmari Merseburgensis episcopi chronicon, ScRG NS IX, ed. R. HOLTZMANN, Berlin 1935, I, 26, s. 22.

31 H.C. Faussner, Zum Regnum Bavariae Herzog Arnulfs (907-938), Wien 1984, s. 32; G. AlthOFF, H. Keller, op. cit., s. 128; C. BRÜHL, Deutschland-Frankreich. Die Geburt zweier Völker, Köln-Wien 1995, s. $474 \mathrm{i} \mathrm{n.}$

32 An. Aug., s. 69 (pod rokiem 938); Cont. Reg., s. 617 (pod rokiem 938); Herimanni..., s. 113 (pod rokiem 937 i 938). Vide: Widukindi..., II, 34, s. 94. 
sukcesem, czego dodatkowym dowodem jest przywrócenie zwierzchności króla nad Kościołem bawarskim ${ }^{33}$.

$\mathrm{Na}$ początku panowania musiał Otton I zmierzyć się jeszcze ze swym bratem Henrykiem. W zasadzie sprzysiężenie to można uważać za kontynuację pierwszego, to jest Thankmara i Eberharda, choć w nieco zmienionej konstelacji. Zgodnie z przekazem Widukinda najpierw Eberhard uzyskał przebaczenie królewskiego brata za przetrzymywanie go w niewoli ${ }^{34}$, czego ceną miało być poparcie przez księcia frankońskiego Henryka w jego buncie przeciw Ottonowi I i pomoc w uzyskaniu korony ${ }^{35}$. Następnie Eberhardowi, spodziewającemu się odzyskać pozycję zajmowaną za czasów Henryka I w wyniku powodzenia spisku, udało się przeciągnąć na swoją stronę księcia lotaryńskiego Giselberta ${ }^{36}$, obawiającego się z kolei polityki Ottona I zmierzającej do ograniczenia samodzielności księstw, co prędzej czy później musiałoby dotyczyć i jego ${ }^{37}$.

Aby umocnić swą pozycję, Henryk udał się na początku 939 r. do Saalfeld, położonego na południe od Erfurtu, gdzie wydał dla swych przyjaciół i zwolenników ucztę, pozyskując ich dla siebie dodatkowo bogatymi nadaniami. By nie wydać się winnymi sporu między braćmi, wielu z uczestników biesiady uważało, że Henryk powinien udać się do Lotaryngii, powierzając obronę grodów i miast w Saksonii oraz Turyngii swoim ludziom. Tak też się stało, a za swoim bratem wraz z armią podążył Otton I. W trakcie pościgu król dotarł pod Dortmund obsadzony przez ludzi Henryka, ale do oblężenia nie doszło, ponieważ załoga twierdzy pomna na los Thankmara w Eresburgu postanowiła wyjść mu naprzeciw i poddać się. Dowódcą Dortmundu był niejaki Agina, którego Ottonowi I udało się zobowiązać do próby nakłonienia Henryka do zawarcia pokoju lub przynajmniej w razie niepowodzenia misji do powrotu do niego, po czym pomaszerował nad $\operatorname{Ren}^{38}$, gdzie na wysokości

33 Vide: An. Iuv. m., s. 743 (pod rokiem 938) - tu mowa jest o wyniesieniu przez Ottona I Herolda na arcybiskupa salzburskiego.

34 Vide: przyp. 25.

35 Widukindi..., II, 12, s. 78. Również Litprand (IV, 22, s. 115) przypisuje Henrykowi ambicje królewskie, jednakże (IV, 21 i 23, s. 116 i n.) twierdzi, że Giselbert pragnął wykorzystać brata Ottona I, by samemu sięgnąć po tę godność, oraz podobnie Eberhard, który w tym celu chciał wykorzystać Giselberta.

${ }^{36}$ LiUTPRAND, IV, 21, s. 115 i n.; Hrotsvithae..., v. 209.

${ }^{37}$ J. SOCHACKI, Formowanie się wczesnośredniowiecznego..., s. 212 i n.

${ }^{38}$ Widukindi..., II, 15, s. 80. 
Birten, po zachodniej stronie rzeki, oczekiwali na niego Henryk i Giselbert. Choć przybyły do obozu Ottona I Agina twierdził, że Henryk spieszy do swego brata tak szybko jak to tylko możliwe z wiernymi służbami, to jednak doszło do bitwy. Dzięki podstępowi i umiejętnemu manewrowi części armii Ottona I, której wcześniej udało się przedostać na zachodni brzeg Renu, doszło w pierwszej połowie marca 939 r. do klęski wojsk księcia lotaryńskiego i brata królewskiego ${ }^{39}$. Z tego opisu wydarzeń zawartego u Widukinda nie wynika niestety, jaką rolę powierzono Dortmundowi i w ogóle jaką taktykę walki ze swym władcą obrali sprzymierzeni. Na szczęście w dziele tak zwanego Kontynuatora Reginona stwierdzono, że ci ostatni chcieli bronić przejścia przez Ren, z czego jasno wynika, że ich cele były na razie ograniczone do defensywy, zatem taka rola przypadła również Dortmundowi, konkretnie zaś opóźnienia marszu w kierunku tej rzeki.

Po zwycięstwie pod Birten Otton I zdecydował się nadal ścigać swego brata i księcia lotaryńskiego, jednakże w tym samym czasie niejaki Dadi rozpowszechnił w Saksonii wiadomość o poniesionej przez sprzymierzonych klęsce i rzekomej śmierci Henryka. W wyniku tego podstępu wszyscy poddali się władzy królewskiej, tak że Henrykowi pozostały wierne jedynie załogi w Merseburgu i Scheidungen ${ }^{40}$. Sprawa była na tyle poważna, że brat króla zdecydował się powrócić do Saksonii, by ratować sytuację, jednakże zamknąwszy się w Merseburgu, został oblężony przez Ottona I. Z dostępnych źródeł wiadomo tylko, że walki trwały dwa miesiące. Z faktu, że Henryk w końcu zdecydował się sam poddać twierdzę przyszłemu cesarzowi, wynika wszakże, że oblegający nie zdołali osiągnąć większych sukcesów, a kapitulacja była skutkiem albo głodu panującego w grodzie, albo beznadziejnego położenia Henryka w Saksonii. W wyniku przeprowadzonych rozmów Henrykowi udało się uzyskać trzydziestodniowy rozejm, w czasie którego zobowiązał się opuścić Saksonię ze swymi ludźmi lub powrócić do brata, który gwarantował mu przebaczenie $^{41}$. O samym Scheidungen nic nie wiadomo, jednakże skoro Widukind twierdzi, że po zawarciu rozejmu w Saksonii na pewien czas zapanował pokój,

39 Ibidem, II, 17, s. 82 i n. O tej bitwie vide: Cont. Reg., s. 618 (pod rokiem 939); LiUtPRAND, IV, 24, s. 117 i n.

40 Widukindi..., II, 18, s. 83.

${ }^{41}$ Ibidem, II, 19, s. 83 i n. Do kapitulacji Henryka doszło krótko przed 7 VI 939 r., kiedy Otton I poczynił darowiznę na rzecz klasztoru św. Maurycego w Magdeburgu - vide: MGH Diplomatum regum et imperatorum Germaniae I, Hannover 1879-1884, nr 21, s. 109. 
to oznacza to najpewniej, że załoga tego grodu poddała się bez walki i podążyła za swym panem.

Henryk po zawarciu rozejmu i opuszczeniu Saksonii zdecydował się udać do swojego szwagra, to jest księcia Lotaryngii, u którego przebywał przez jakiś czas. Giselbert w tym czasie doprowadził w końcu do zawarcia sojuszu z królem Ludwikiem IV Zamorskim, co skłoniło Ottona I do zorganizowania przeciw niemu wyprawy wojennej ${ }^{42}$. Armia królewska, wkroczywszy na wrogi teren, dokonała wielu zniszczeń tamtejszych miejscowości, biorąc przy tym bardzo bogate łupy ${ }^{43}$. Giselbert postanowił zatem schronić się w Chevermont pod Lüttich. Twierdza ta była niezwykle trudna do zdobycia dzięki swemu naturalnemu położeniu i umocnieniom ${ }^{44}$, nic zatem dziwnego, że nie doszło do jej zajęcia, mimo że Giselbert zbiegł z niej w trakcie oblężenia. W tej sytuacji Otton I zdecydował się dokonać spustoszenia okolicy ${ }^{45}$ i aby trzymać księcia lotaryńskiego w szachu, przeciągnął na swą stronę hrabiego Immo. W związku z tym ostatnim warto wspomnieć o anegdocie przytoczonej przez Widukinda, mającej jednak bardziej charakter legendarny niż autentyczny. Wedle przekazu książę Giselbert, rozgniewany na hrabiego za podstępne zrabowanie mu stada świń, postanowił go oblegać w niewymienionym z nazwy grodzie. Immo, posiadający liczne ule, postanowił rozrzucić je wśród jazdy Giselberta i widząc wybuchłe zamieszanie, zbierał się do zbrojnego wypadu z grodu. Tym i innymi podstępami został w końcu książę lotaryński zmuszony do zwinięcia oblężenia ${ }^{46}$.

W trakcie oblężenia Chevermont w czerwcu 939 r. wyprawił się Ludwik IV Zamorski przez Verdun do Alzacji, ale dowiedziawszy się o zbliżaniu się Ottona I pod Breisach i buncie możnych w swoim kraju, postanowił wycofać się do Laon $^{47}$. Zapewne po odwrocie króla zachodniofrankijskiego postanowił

42 O tym sojuszu - vide: Flod. an., s. 385 i n. (pod rokiem 939).

43 Wspomina o tym: FLODOARD (vide przypis powyżej); Richeri historiarum libri quatuor, MGH SS III, ed. G.H. PERTZ, Hannover 1839, II, 18, s. 591.

${ }^{44}$ LiUTPRAND, IV, 34, s. 127. O trudnościach oblężenia związanych z położeniem Chevermont wspomina też Widukindi..., II, 22, s. 86.

${ }^{45}$ Widukindi..., II, 22, s. 86. O dotarciu Ottona I pod Chevermont i jego oblężeniu krótko wspominają: An. Aug., s. 69 (pod rokiem 939); Cont. Reg., s. 618 (pod rokiem 939); Herimanni..., s. 113 (pod rokiem 939).

46 Widukindi..., II, 23, s. 86.

${ }^{47}$ J. Sochacki, Formowanie się wczesnośredniowiecznego..., s. 265; IDEM, Początki państw..., s. 97 i n. 
Otton I przystąpić do oblężenia Breisach, obsadzonego przez ludzi Eberharda. Znaczenie Breisach było bardzo duże, ponieważ dzięki niemu książę frankoński zapewniał sobie panowanie nad Alzacją ${ }^{48}$ oraz mógł nawiedzać wojną okolicznych zwolenników króla ${ }^{49}$. Twierdza ta, podobnie jak Chevermont, była trudna do zdobycia ze względu na swe położenie, to jest na wyspie Renu, dlatego też Otton I zdecydował się na podjęcie rokowań z Eberhardem za pośrednictwem arcybiskupa mogunckiego Fryderyka. W wyniku przeprowadzonych rozmów doszło do ustalenia warunków pokoju, zaprzysiężonych przez wysłannika królewskiego. Na te warunki Otton I jednak nie chciał się zgodzić i dlatego odesłał Fryderyka ponownie do księcia frankońskiego w celu ich odwołania i przedstawienia prawdziwych żądań króla ${ }^{50}$. Ta nieprzejednana postawa władcy wschodniofrankijskiego była zdaniem Widukinda przyczyną ogólnego odstąpienia od króla ${ }^{51}$. Dodatkowym zagrożeniem był zamiar Giselberta i Eberharda przekroczenia Renu. Na szczęście dla Ottona I ich wojska udało się pokonać 2 października 939 r. ${ }^{52}$ pod Andernach wiernym mu przedstawicielom rodu Konradynów, w wyniku czego Eberhard poległ w walce, a Giselbert utonął w Renie podczas ucieczki ${ }^{53}$. Skutki tej bitwy były natychmiastowe: po pierwsze, skapitulowała załoga Breisach ${ }^{54}$,

${ }^{48}$ O znaczeniu Breisach - vide: G. HesELIER, Geschichte der Stadt Breisach am Rhein, Halbbd. 1: Von den Anfängen bis zum Jahr 1700, Breisach am Rhein 1969, s. 56 i n.; W. GLOCKER, op. cit., s. 65.

49 Liutprand, IV, 27, s. 122. O oblężeniu Breisach nadmieniają: An. Aug., s. 69 (pod rokiem 939); Cont. Reg., s. 618 (pod rokiem 939), podkreślające znakomite obwarowania tej twierdzy, oraz Widukindi..., II, 24, s. 87, który ponadto dodaje, że doszło też do prób zdobycia innych umocnionych placówek Eberharda.

50 Postawa arcybiskupa Fryderyka w tych i innych rokowaniach ściągnęła na niego podejrzenie sprzyjania spiskowcom - o motywach, jakimi się kierował ten dostojnik kościelny, vide: J. Dierauer, Ruotger und der Aufstand von 953. Eine kritische Untersuchung, [w:] Untersuchungen zur mittleren Geschichte, hrsg. v. M. BÜDINGER, Bd. III, Abt. 1, Leipzig 1871, s. 8 i n.; A. MiTTAG, Erzbischof Friedrich von Mainz und die Politik Ottos des Großen, Berlin 1895; W. Norden, Erzbischof Friedrich von Mainz und Otto der Grosse. Zur Entwicklung des deutschen Staatsgedankens in der Ottonenzeit, Berlin 1912.

${ }^{51}$ Widukindi..., II, 25, s. 87 i n. O żądaniach Eberharda - vide: J. SoCHACKI, Formowanie sie wczesnośredniowiecznego..., s. 215 i n.; J. STRZELCZYK, op. cit., s. 85.

52 Do datacji bitwy - vide: C. BRÜHL, op. cit., s. 478, przyp. 124.

53 J. Sochacki, Formowanie się wczesnośredniowiecznego..., s. 216; IDEM, Początki państw..., s. 98; J. STRZelCZYK, op. cit., s. 86. Źródła do tej bitwy vide: R. KöpKe, E. DümmLer, Kaiser Otto der Große, Leipzig 1876, s. 91, przyp. 5.

${ }^{54}$ Cont. Reg., s. 618 (pod rokiem 939). 
a po drugie, po przeprowadzeniu jeszcze w tym roku wyprawy do Lotaryngii i jej pacyfikacji, mimo krótkotrwałego oporu biskupa Metzu Adalbero ${ }^{55}$, poddał się swemu królewskiemu bratu Henryk, co oznaczało zakończenie tego buntu ${ }^{56}$.

Do ponownego buntu przeciw Ottonowi I doszło dopiero około dziesięciu lat później ${ }^{57}$. Tym razem władca wschodniofrankijski musiał się zmierzyć z własnym synem Liudolfem, konkurującym o pozycję w państwie ze swym stryjem Henrykiem ${ }^{58}$. Do tego wystąpienia przyłączył się też nieco później Konrad Czerwony, książę lotaryński. Po raz pierwszy do wyraźnego skrzyżowania się interesów Liudolfa i Henryka doszło na terenie Italii ${ }^{59}$. Syn Ottona I obawiał się zlekceważenia swych roszczeń w tym kierunku tak ze strony ojca, który ostatecznie wyruszy tam we wrześniu 951 r., jak i nawet bardziej ze strony swego stryja, któremu z kolei nieco wcześniej udało się opanować Akwileję ${ }^{60}$. By temu zapobiec, Liudolf wkroczył do Italii latem tego roku i to bez wiedzy swego ojca. Kampania ta nie została ukoronowana sukcesem, a przyczyny jej niepowodzenia wyraźnie tym razem wskazują na rolę miast i twierdz w objęciu rzeczywistej władzy nad danym obszarem. Jak zapisał Kontynuator Reginona, Henryk, zazdrosny o wszelkie objawy pomyślności swego bratanka, miał wysłać z Bawarii przez Trydent posłów do Italii, by odwrócić od niego umysły jej mieszkańców. Misja ta zakończyła się powodzeniem, tak że żaden zamek czy miasto nie otwarły mu bram, i wszystko tam okazało się dla Liudolfa niesprzyjające i pełne utrapieńn ${ }^{61}$. Nieco mniej pesymistyczny obraz szkicuje Widukind, twierdząc, że udało mu się jednak opanować pewne miasta, ale dalej pisze już o opuszczeniu przez niego Italii, po pozostawieniu tam załóg wojskowych, tak więc i on nie zdołał ukryć

55 Ibidem, s. 618 (pod rokiem 939), podaje, że w celu stawienia oporu Adalbero nakazał zniszczyć wybudowaną jeszcze przez cesarza Ludwika Pobożnego kaplicę w Thionville, by nie służyła jako fortyfikacja dla jego przeciwników.

${ }^{56}$ O próbie zamachu na Ottona I w 941 r., w którym miał uczestniczyć Henryk, vide: J. SOCHACKI, Formowanie się wczesnośredniowiecznego..., s. 217; IDEM, Początki państw..., s. 99; J. STRZELCZYK, op. cit., s. 87.

57 Źródła do buntu Liudolfa w latach 953-954 vide: K. ReINDEL, op. cit., nr 104, s. 204 i n.

${ }_{58}$ Motywy wystąpienia Liudolfa przeciw ojcu vide: J. SOCHACKI, Formowanie się wczesnośredniowiecznego..., s. 230 i n.; IDEM, Poczattki państw..., s. 106 i n.; J. STRZELCZYK, op. cit., s. 172 i n.

59 O wcześniejszych sporach granicznych między nimi informują: Gerhardi vita sancti Oudalrici episcopi Augustani, MGH SS IV, ed. G. WAITZ, Hannover 1841, c. 10, s. 398.

${ }^{60}$ Widukindi..., II, 36, s. 95.

${ }^{61}$ Cont. Reg., s. 621 (pod rokiem 951). 
fiaska przedsięwzięcia Liudolfa ${ }^{62}$. Choć był rozczarowany tym niepowodzeniem, postanowił się przyłączyć do swego ojca, gdy ten wreszcie wkroczył do Italii $^{63}$, niezadowolony wszak z jego ożenku z wdową po królu Lotarze Adelajdą, opuścił bez zezwolenia armię ${ }^{64}$ i udał się do ojczyzny, gdzie Boże Narodzenie świętował w Saalfeld ${ }^{65}$.

Spisek Liudolfa i Konrada Czerwonego ujawniono krótko przed Świętami Wielkanocnymi 3 kwietnia 953 r. Otton I, bojąc się o swe bezpieczeństwo, porzucił zamiar ich spędzenia w Ingelheim i udał się do Moguncji, gdzie też przybyli jego syn i książę lotaryński. Przy pośrednictwie arcybiskupa mogunckiego Fryderyka doszło tam do rozmów i zawarcia układu, o którego treści jednak nic nie wiadomo. Król po opuszczeniu Moguncji udał się do Dortmundu, gdzie odwołał dopiero co zawarty układ jako wymuszony oraz wezwał Liudolfa i Konrada Czerwonego do wydania przywódców spisku, o ile sami nie chcą być uznani za wrogów państwa. Na zwołanym wkrótce potem zgromadzeniu we Fritzlarze pojawił się tylko arcybiskup Fryderyk, co skłoniło Ottona I do surowego wystąpienia przeciw spiskowcom i być może do pozbawienia księstwa Konrada Czerwonego ${ }^{66}$. W zaistniałej sytuacji konflikt zbrojny między ojcem a synem i zięciem stawał się nieunikniony.

Nim doszło do działań zbrojnych spiskowcy, według zapewnień biografa arcybiskupa Brunona z Kolonii, starali się opanować jak największą liczbę grodów, zwłaszcza Moguncję i Kolonię, wierząc, że dzięki temu z łatwością opanują pozostałą część królestwa oraz w wypadku Lotaryngii skłonią jej mieszkańców do

${ }^{62}$ Widukindi..., III, 6, s. 108. Vide inne źródła informujące o wyprawie Liudolfa do Italii: Herimanni..., s. 114, (pod rokiem 952); Annales Altahenses maiores, MGH SS XX, ed. L.B. AB OEFELE, Hannover 1989, s. 786 (pod rokiem 952); НROTSVITHA, v. 608-613, s. 221 i n.

${ }^{63} \mathrm{~W}$ sprawie czasu wkroczenia Ottona I do Italii oraz problemu miejsca przyłączenia się do niego Liudolfa vide: R. KÖPKE, E. DÜMMLER, op. cit., s. 194, przyp. 1 i 5.

${ }^{64}$ Tylko Hrotsvitha (v. 668-670) uważa, że to Otton I postanowił wysłać Liudolfa do ojczyzny jako swego namiestnika.

${ }_{65}$ Widukindi..., III, 9, s. 109; Con. Reg., s. 621 (pod rokiem 951) i s. 621 (pod rokiem 952). O znaczeniu Saalfeld vide: G. ALTHOFF, Zur Frage nach der Organisation der sächsischen coniurationes in der Ottonenzeit, „Frühmittelalterliche Studien” 1982, R. 16, s. 129 i n.; IDEM, Breisach - ein Refugium für Rebellen im frühen Mittelalter?, [w:] Archäologie und Geschichte des ersten Jahrtausends in Südwestdeutchland, Sigmaringen 1990, s. 465 i n. Ciekawe uwagi odnośnie do spotkania w Saalfeld i odprawionej tam uczty - vide: G. Wolf, Liudolfs „Gelage” in Saalfeld Weihnachten 951, „Zeitschrift für Rechtsgeschichte” 1985, R. 102, GA, s. 322 i n.

${ }^{66}$ J. SOCHACKI, Formowanie się wczesnośredniowiecznego..., s. 224 i n. 
zachowania pokoju lub przez częste wrogie ataki wzbudzą w nich strach ${ }^{67}$. Słowa te wyraźnie świadczą o tym, jakie znaczenie dla Liudolfa i Konrada miały miasta we Frankonii i w Lotaryngii w planowanym oporze przeciw królowi. Potwierdza to też reakcja Ottona I, który w lipcu 953 r. wyruszył przeciw przywódcom tego buntu. Nim władca wschodniofrankijski dotarł pod Moguncję zdołał przejąć pewne twierdze znajdujące się w rękach jego nieprzyjaciół, siłą bądź też dzięki dobrowolnej kapitulacji, po czym nastąpiło oblężenie stolicy Frankonii. Przy jej oblężeniu, trwającym jakieś dwa miesiące, atakujący podtaczali pod mury machiny oblężnicze, które jednak zostały przez grodzian zniszczone lub spalone. Walczono też pod bramami miasta, ale jego załoga rzadko tylko czyniła wypady na zewnątrz ${ }^{68}$. Mimo tych zażartych walk Moguncja nie została szczelnie opasana przez oblegających, co umożliwiło Konradowi Czerwonemu i Liudolfowi wymarsz z miasta i to zapewne ze znacznymi siłami, by zaatakować spieszące do Ottona I posiłki z Saksonii. Do ataku na owe posiłki doszło, gdy ledwo przekroczyły granicę Frankonii. Nie mogąc sprostać przeważającej sile wroga, zaatakowane oddziały postanowiły się schronić w opuszczonej warowni ${ }^{69}$. Przy próbie jej zajęcia stojący przy bramie chorąży utracił ramię w wyniku trafienia jakimś okrągłym przedmiotem, po czym doszło do przerwania walk i zawarcia trzydniowego rozejmu, by umożliwić zaatakowanym powrót do Saksonii ${ }^{70}$.

${ }^{67}$ Ruotgeri vita Brunonis archiepiscopi Coloniensis, ScRG SN X, ed. I. OTT, Weimar 1951, c. 15, s. 14 , c. 19 , s. 18 i c. 24 , s. 25. Vide: c. 20, s. 20, gdzie Otton I skarży się, że arcybiskup moguncki Fryderyk postąpiłby lepiej, gdyby to, co zostało mu dane z łaski królewskiej, oddał swemu prawowitemu władcy niż jego wrogom. Słowa te wprawdzie wyrażają oczekiwania Ottona I wobec episkopatu i to jak widział jego rolę w państwie, ale mimo to i z nich przebija znaczenie, jakie posiadała Moguncja. O umacnianiu fortyfikacji i zamków pisze też Cont. Reg., s. 622 (pod rokiem 953) oraz tamże o powierzeniu przez arcybiskupa Fryderyka obrony Moguncji wrogom króla.

${ }^{68}$ Widukindi..., III, 18, s. 113. O oblężeniu Moguncji vide: czerpiący z Widukinda Thietmari..., II, 6, s. 44; Cont. Reg., s. 622 (pod rokiem 953); An. Aug., s. 69 (pod rokiem 953); Ruotgeri..., c. 16, s. 14; An. Alt. m., s. 786 (pod rokiem 953); Annales Hildesheimenses, ScRG VIII, ed. G. WaITZ, Hannover 1878, s. 21 (pod rokiem 953); An. Qued., s. 58 (pod rokiem 953); Annales Weissemburgenses, MGH SS III, ed. G.H. PERTZ, Hannover 1839, s. 59 (pod rokiem 953); Flod. an., s. 402 (pod rokiem 953 ) - ten ostatni zgadza się z Widukindem, że oblężenie trwało dwa miesiące.

69 Ta opuszczona warownia to zapewne umocnienia sprzed X w., służące jako miejsce schronienia dla okolicznej ludności w razie zagrożenia wojennego. Wiele z nich polecił Henryk I odnowić tajemniczym milites agrarii w ramach przygotowań do odparcia najazdu Węgrów i podboju Słowiańszczyzny Połabskiej - vide: J. SoCHACKI, Formowanie się wczesnośredniowiecznego..., s. 199 i n. Skoro ta warownia do tego czasu nie została odnowiona, to jasne jest, że nie posiadała żadnego znaczenia strategicznego.

${ }^{70}$ Widukindi..., III, 23, s. $115 \mathrm{i}$. 
Bezskuteczne oblężenie Moguncji oraz zmuszenie do wycofania się armii posiłkowej skłoniło Ottona I do nawiązania rozmów pokojowych. W ich trakcie Liudolf i Konrad zgłosili gotowość poddania się, ale zażądali od króla, by ich poplecznicy zostali przywróceni do jego łask oraz nie doznali żadnych prześladowań. Tego jednak warunku Otton I nie chciał spełnić, co też oznaczało fiasko rokowań ${ }^{71}$. W ciągu najbliższej nocy po nieudanych rozmowach pokojowych Liudolf opuścił oblegany gród w towarzystwie Bawarów, których pod Moguncję przywiódł Henryk, i podążył do Ratyzbony. Zajęcie przez Liudolfa tego ośrodka, jak i innych twierdz, przebiegło bez większych trudności dzięki wcześniejszemu nawiązaniu przyjaznych stosunków z palatynem Arnulfem, synem księcia Arnulfa bawarskiego, któremu była powierzona władza nad Bawarią. Po opanowaniu Ratyzbony Liudolf, zapewne by umocnić swoich ludzi w wierności, rozdzielił między nich skarb Henryka oraz doprowadził do opuszczenia tej krainy przez małżonkę swego stryja wraz z jej dziećmi i przyjaciółmi ${ }^{72}$. Natomiast Konrad Czerwony jakiś czas po opuszczeniu przez Liudolfa Moguncji zawarł z Ottonem I układ i następnie udał się do Lotaryngii, pozostawiając jednak załogę w obleganym dotąd grodzie. W tych okolicznościach Otton I postanowił zwinąć oblężenie i udać się za swoim synem, a zadanie pacyfikacji Lotaryngii powierzył swemu bratu Brunonowi, któremu przekazał to księstwo, być może z tytułem księcia lub arcyksięcia ${ }^{73}$.

Konrad Czerwony, powróciwszy do Lotaryngii, zwrócił się przeciw biskupowi Adalbero, zajmując podstępem jego siedzibę biskupią, czyli Metz. Jego okupacja tego ośrodka nie trwała jednak długo, ponieważ opuścił go nakłoniony do tego przez opata Eginolda z Gorze, ale po dokonaniu wielkich rabunków $^{74}$. W międzyczasie zagroził również Kolonii i innym twierdzom ${ }^{75}$, ale bez większych rezultatów, oraz splądrował Trewir ${ }^{76}$. W swych walkach z arcybiskupem kolońskim Brunonem Konrad Czerwony nie wahał się też sprzy-

${ }^{71}$ J. SOCHACKI, Formowanie się wczesnośredniowiecznego..., s. 226.

${ }^{72}$ Ruotgeri.., c. 19, s. 18 i n.; Cont. Reg., s. 622 (pod rokiem 953); Widukindi..., III, 20, s. 115.

73 J. SOCHACKI, Formowanie się wczesnośredniowiecznego..., s. 226 i n.

${ }^{74}$ Flod. an., s. 402 (pod rokiem 953).

75 Vide przyp. 67. O walkach Konrada Czerwonego w Lotaryngii vide: F. PRINZ, Klerus und Krieg im früheren Mittelalter. Untersuchungen zur Rolle der Kirche beim Aufbau der Königsherrschaft, Stuttgart 1971, s. 175 i n.; P. SCHWENK, Brun von Köln (925-965). Sein Leben, sein Werk und seine Bedeutung, Espelkamp 1995, s. 109.

${ }^{76}$ Vide: R. KÖPKe, E. DÜMMLER, op. cit., s. 228, przyp. 3. 
mierzyć z Węgrami, którzy na początku 954 r. dokonali najazdu na państwo wschodniofrankijskie. Opuszczony przez wielu zwolenników, oburzonych jego związkami z pogańskimi najeźdźcami, oraz nie mogąc pokonać Brunona, zdecydował się Konrad w końcu na zawarcie z nim rozejmu w Bliesgau pod Rümlingen, a także zapewne zobowiązał się pojawić w Langenzen na pokojowe rokowania. Obok niego zjawili się tam 16 czerwca 954 r. również arcybiskup moguncki Fryderyk i sam Liudolf. W ostatecznym rezultacie tego zgromadzenia przy oporze wobec Ottona I pozostał tylko jego syn Liudolf, podczas gdy dwaj pozostali przeszli na stronę króla ${ }^{77}$.

Równie dramatycznie przebiegały wydarzenia w Bawarii, gdzie Otton I wyprawił się w 953 r. tylko z nieznacznymi siłami ${ }^{78}$, na szczęście jednak wspartymi przez oddziały biskupa Augsburga Udalryka ${ }^{79}$. Zdaniem Widukinda po wkroczeniu Ottona I do tego księstwa jego mieszkańcy nie chcieli zawrzeć pokoju ani nie ważyli się stoczyć otwartej walki, lecz zamknięci za murami, zgotowali królewskiej armii wielkie trudności. Doszło jednak zapewne do jakichś walk partyzanckich, skoro niejaki Mainwerk zginął od strzały w trakcie marszu do Bawarii. Samo oblężenie Ratyzbony trwało około trzech miesięcy i poza spustoszeniem okolicy nie przyniosło niczego więcej, tak że przed świętami Bożego Narodzenia Otton I postanowił wrócić do Saksonii ${ }^{80}$. Zaangażowanie się biskupa Udalryka pod Ratyzboną postanowił wykorzystać palatyn Arnulf, który dokonał najazdu na jego diecezję, zdobywając i plądrując jednocześnie jej stolicę Augsburg. Zdobycie tego grodu nie było raczej trudne, ponieważ, jak wspomniano, Udalryk przebywał wtedy pod Ratyzboną zapewne ze znaczną częścią pozostających do jego dyspozycji sił zbrojnych, skutkiem czego załoga Augsburga nie była odpowiednio liczna i nie mogła stawić skutecznego oporu, ponadto jego opanowanie ułatwiał stan umocnień miasta, to jest niskie mury pozbawione całkowicie wież $\dot{z}^{81}$. Arnulf wraz z łupami oraz jeńcami opuścił Szwabię i powrócił do Bawarii ${ }^{82}$.

77 J. SOCHACKI, Formowanie się wczesnośredniowiecznego..., s. 227 i n.

78 Widukindi..., III, 21, s. 115.

79 Gerhardi..., c. 10, s. 399.

${ }^{80}$ Widukindi..., III, 26, s. 116 i III, 28, s. 117. O oblężeniu Ratyzbony vide: Cont. Reg., s. 622 (pod rokiem 953).

${ }^{81}$ Gerhardi..., c. 12, s. 401.

82 Ibidem, c. 10, s. 399. O splądrowaniu biskupstwa i jego stolicy Augsburga informuje również Herimanni..., s. 114 (pod rokiem 953). 
Działania wojenne przerwał tylko na krótki czas najazd Węgrów na początku 954 r. Unikali oni jednak starcia z Ottonem I, który szybko przeciw nim wyruszył, dlatego też zdecydował się on skierować swe siły przeciw Bawarii $^{83}$. Ostatecznie doszło do zawarcia rozejmu i pojawienia się w czerwcu Liudolfa, Konrada Czerwonego oraz arcybiskupa Fryderyka w Langenzen, o czym była już powyżej mowa. Ponieważ Liudolf nie chciał pojednać się z ojcem, w przeciwieństwie do swych towarzyszy, postanowił on w najbliższą noc po rokowaniach opuścić Langenzen i udać się do Ratyzbony. Natychmiast podążył za nim Otton I, który usiłował najpierw zdobyć Rosstal, położony na południowy zachód od Norymbergi, trzy dni marszu od Ratyzbony. Oblężenie nie trwało długo i po stoczeniu zaciętej walki, w której po obu stronach odniesiono znaczne straty, król postanowił przerwać bój i skierować swą armię ku poważniejszym zadaniom, czyli próbie opanowania stolicy Bawarii ${ }^{84}$. Po przybyciu pod Ratyzbonę Otton I nie zdecydował się na otoczenie miasta szczelnym kordonem, zapewne z powodu zbyt małej liczby żołnierzy, lecz nakazał wyszukać miejsce na obóz, który otoczono umocnieniami. Z kolei liczba obrońców była na tyle znaczna, że niemożliwe okazało się podtoczenie pod mury miasta machin oblężniczych i z tego też powodu toczono tam ciężkie boje. Przedłużające się oblężenie i obawa obrońców przed głodem skłoniły ich do próby opanowania obozu królewskiego. Postanowiono zatem, że oddział konnych wyruszy z zachodniej bramy w celu symulowania ataku na obóz, natomiast piesi żołnierze mieli na statkach tam podpłynąć i dokonać prawdziwego ataku na opuszczoną przez wojowników placówkę. Sygnałem do rozpoczęcia całej akcji był dźwięk dzwonu. Sygnał ten był jednak znany pozostającym w obozowisku wrogom, co umożliwiło im odpowiednie przygotowania, a dodatkową przyczyną niepowodzenia atakujących był brak koordynacji w ich działaniach, spowodowany opóźnionym wyruszeniem konnych. Miara klęski się dopełniła, gdy Henrykowi udało się przejąć bydło przeciwnika, wypasające się między rzekami Regen i Dunaj, co dla oblężonych oznaczało początek głodu $^{85}$. Zdesperowany Liudolf usiłował najpierw zawrzeć z ojcem pokój, ale bez powodzenia, a następnie zaatakował obozującego pod wschodnią bramą margrabiego Gerona. I tym razem bez powodzenia, co gorsza - w trakcie tej

\footnotetext{
83 Widukindi..., III, 30 i 31, s. 117 i n.

${ }^{84}$ Ibidem, III, 33 i 34, s. 119 i n.

85 Ibidem, III, 36, s. 120 i n.
} 
walki zginął palatyn Arnulf ${ }^{86}$, co doprowadziło po półtoramiesięcznym oblężeniu do ponownych pertraktacji pokojowych. W ich wyniku zawarto rozejm oraz wyznaczono Fritzlar jako miejsce rozstrzygnięcia sporu ${ }^{87}$. Nim jednak doszło do tego umówionego spotkania Liudolf przybył do ojca pod koniec października 954 r. do Tangelstadt, gdzie boso u jego stóp przyrzekł posłuszeństwo i uległość, w zamian za co został przywrócony do łaski. Do ostatecznego pojednania się ojca z synem i Kon radem Czerwonym doszło dopiero w grudniu 954 r. na zgromadzeniu w Arnstadt ${ }^{88}$. Warto jeszcze wspomnieć, że po zawarciu rozejmu udało się Henrykowi zdobyć część Ratyzbony, położonej po lewej stronie Dunaju, reszta zaś miasta spłonęła niemal doszczętnie najbliższej nocy $^{89}$. Losy tego grodu dopełniły się w kwietniu 955 r., tym razem ostatecznie opanowanego bez walki przez Ottona I, który następnie skazał przywódców powstania na wygnanie, okazując pozostałym łaskę, oraz przekazał księstwo bawarskie swemu bratu ${ }^{90}$. Dla ostatecznego zakończenia tego powstania duże znaczenie miała również nieco wcześniejsza kapitulacja Moguncji i tym samym całej Frankonii po śmierci arcybiskupa Fryderyka 25 października 954 r. ${ }^{91}$

W 954 r., tak jak rok wcześniej, doszło również do działań wojennych w Szwabii. Po wycofaniu się Ottona I pod koniec 953 r. z Bawarii sytuacja Udalryka była niezwykle trudna, ponieważ Liudolf i jego zwolennicy rozdzielili niemal wszystkie posiadłości jego diecezji w lenno „obcym”, a ponadto wielu żołnierzy biskupa albo ujęli w niewolę, albo przekonali ich do niedotrzymania mu wierności lub też plądrując ich dobra, doprowadzili ich do takiej nędzy, że nie mogli świadczyć swemu suwerenowi służb w takim zakresie, do jakiego byli zobowiązani ${ }^{92}$. W tej sytuacji Udalryk zwątpił w możliwość utrzymania się w Augsburgu ze szczupłymi siłami, którymi jeszcze dysponował. Podobnie uważało też jego otoczenie, doradzające mu opuszczenie miasta

${ }^{86}$ Wiadomość o śmierci Arnulfa znajduje się także u Gerhardi..., c. 11, s. 400.

87 Widukindi..., III, 37 i 38, s. 121.

${ }^{88}$ J. SOCHACKI, Formowanie się wczesnośredniowiecznego..., s. 229.

89 Widukindi..., III, 39, s. 122.

90 Ibidem, III, 43, s. 123.

${ }^{91}$ Ibidem, III, 41, s. 122.

92 Zdaniem H.W. KlewitZA, Das alemannische Herzogtum bis zur staufischen Epoche. Aufgaben und Probleme der Erforschung sieiner inneren Entwicklung und ibrer geistlichen Voraussetzungen, [w:] Oberrheiner, Schwaben, südalemannischen Räume und Kräfte im geistlichen Aufbau des deutschen Südwesen, hrsg. v. F. MAURER, Straßburg 1942, s. 83 - szerokie poparcie dla Liudolfa w Szwabii nie wynikało z tamtejszych dążeń separatystycznych, lecz z wierności wasala wobec swego pana lennego. 
i wycofanie się do Schwabmünchen ${ }^{93}$, gdzie po przeprowadzeniu odpowiednich prac zaistniałaby możliwość oporu wobec wrogów. Już następnego dnia Udalryk wyruszył do wskazanego miejsca, opuszczonego na zewnątrz i wewnątrz oraz pozbawionego jakichkolwiek budowli. Mimo ostrej zimy obozowano w namiotach i pospiesznie zbudowanych chatach, aż zebrali się ludzie biskupa, którzy otoczyli gród palisadą oraz wznieśli w nim konieczne zabudowania. Na wieść o tym Arnulf wysłał do Udalryka poselstwo z żądaniem, by podporządkował się władzy Liudolfa oraz zaprzestał dalszego umacniania grodu, wskazując jednocześnie na fakt, że biskup nie może liczyć na nikogo poza swoim bratem Ditpoldem i Adalpertem. Udalryk nie omieszkał wykorzystać nadarzającej się okazji i dzięki umiejętnemu przeciąganiu pertraktacji zdołał doprowadzić do zaprzestania wypadów wrogów, a także do dokończenia budowy umocnień Schwabmünchen, po czym oświadczył Arnulfowi, że zamierza nadal trwać w wierności wobec króla. W tej sytuacji palatyn zmobilizował swe siły z zamiarem wyruszenia przeciw biskupowi i zmuszenia go do posłuszeństwa wobec Liudolfa. Udalryk usiłował jeszcze przeciwdziałać temu niebezpieczeństwu, wysyłając ponownie poselstwo do Arnulfa z prośbą o pozostawienie go w pokoju oraz obiecując w wypadku jej wypełnienia wiele pieniędzy, jeżeli jednak tego nie uczynią, zagroził ekskomuniką tym, którzy dopuszczą się jakichkolwiek przewinień wobec dóbr jego biskupstwa. Mimo tych obietnic i gróźb Arnulf nie wstrzymał marszu i 5 lutego 954 r. rozpoczął oblężenie Schwabmünchen. Dzielna postawa obrońców umożliwiła im doczekanie odsieczy przywiedzionej przez Adalperta i Dietpolda, którzy zaatakowali wojska palatyna 13 lutego 954 r. Oblegający, zaskoczeni takim obrotem sprawy, nie stawiali skutecznego oporu i pozostawiając zdobyte łupy, szukali ratunku w ucieczce. W wyniku tej potyczki do niewoli dostał się brat Arnulfa

93 S. RieZler, Geschichte Baierns, Bd. I, Gotha 1878, s. 344. Autor przyjąt, że gród ten to Merching nad górną Paarą - tak też np. K. WeLLER, Geschichte des schwäbischen Stammes bis zum Untergang der Staufer, München-Berlin 1944, s. 170. W nowszej literaturze przyjmuje się jednak, że chodziło prawdopodobnie o Schwabmünchen - vide: K. ReINDEL, op. cit., s. 213; IDEM, Bayern vom Zeitalter der Karolinger bis zum Ende der Welfenherrschaft, [w:] Handbuch der bayerischen Geschichte, hrsg. v. M. SPINDler, München 1981, s. 293; W. GOEZ, Gestalten des Hochmittelalter. Personengeschichtliche Essays im allgemeinhistorischen Kontext: Bischof Ulrich von Augsburg (923-973), Darmstadt 1983, s. 35; M. WeITlauff, Bischof Ulrich von Augsburg (923-973). Leben und Wirken eines Reichsbischof der ottonischen Zeit, [w:] Bischof Ulrich von Augsburg 890-973. Seine Zeit-sein Leben-seine Verehrung, hrsg. v. M. Weitlauff, Weißenhan 1993, s. 116. 
Herman, a Adalpert zmarł w wyniku odniesienia rany w ramię ${ }^{94}$. Działania wojenne w Szwabii zakończył wypad Ottona I, który nad rzeką Illerą, nieopodal Illertissen, natknął się na wojska swego syna. Do bitwy jednak nie doszło dzięki pośrednictwu biskupów Udalryka i Hardperta z Chur ${ }^{95}$.

We wszystkich trzech buntach przeciwko Ottonowi I uwidoczniła się duża rola miast i grodów. Polegała ona głównie na tym, że pozwalała spiskowcom na umocnienie swej pozycji w regionie, dzięki czemu wzrastały szanse powodzenia ich przedsięwzięcia. Tak było w wypadku Thankmara po opanowaniu przez niego Eresburga, a zwłaszcza Laër obsadzonego przez ludzi księcia Eberharda frankońskiego, w następnym sprzysiężeniu grodów w Saksonii i Turyngii, Chevermont i Breisach, a także w Italii, gdzie Liudolf usiłował osiągnąć władzę, w wypadku Moguncji, Ratyzbony i Schwabmünchen. Nie znaczy to jednak, że zwycięstwa odniesione w polu miały mniejsze znaczenie, czego dowodzą zwłaszcza wydarzenia w trakcie drugiego buntu, kiedy to po klęsce pod Birten poddały się Ottonowi I wszystkie grody w Saksonii oprócz Merseburga i Scheidungen, oraz po bitwie pod Andernach, gdy skapitulowało Breisach. Posiadanie wszelkiego rodzaju umocnionych placówek było również istotne z tego względu, że przy ówczesnych możliwościach technicznych, mimo zastosowania machin oblężniczych, były one niezmiernie trudne do zdobycia. We wszystkich trzech buntach Ottonowi udało się zdobyć wyłącznie Eresburg, ale tylko dlatego, że jego mieszkańcy otworzyli mu bramy grodu, natomiast w pozostałych wypadkach kapitulacja następowała dobrowolnie, spowodowana niekiedy beznadziejną sytuacją oblężonych, to jest głodem lub brakiem nadziei na odsiecz. Jako przykłady można w tym wypadku wymienić: Laër, Dortmund, Merseburg i prawdopodobnie Scheidungen, natomiast jako zakończone niepowodzeniem: Chevermont, Moguncję (która skapitulowała dopiero po śmierci arcybiskupa Fryderyka i przejściu Konrada Czerwonego oraz Liudolfa na stronę Ottona I), Ratyzbonę (zdobyta ostatecznie po kapitulacji Liudolfa) i Rosstal.

94 Gerhardi..., c. 10, s. 399 i n. Vide: Herimanni..., s. 114 (pod rokiem 953).

95 Gerhardi..., c. 12, s. 400 i n.; Herimanni..., s. 114 (pod rokiem 953). Gerhard napisal, że wskutek pośrednictwa obu biskupów doszło też do zawarcia między ojcem a synem pokoju, co jest sprzeczne z wiadomościami podanymi przez Widukinda (III, 31) - vide: R. KÖPKE, E. DÜMMLER, op. cit., s. 239 i n., gdzie przyjmuje się, że właśnie w tym momencie mogło dojść do uzgodnienia spotkania w Langenzen. 


\section{BIBLIOGRAFIA}

\section{Źródła drukowane}

Annales Altahenses maiores, MGH SS XX, ed. L.B. ab Oefele, Hannover 1989.

Annales Augienses, MGH SS I, ed. G.H. Pertz, Hannover 1826.

Annales Hildesheimenses, ScRG VIII, ed. G. Waitz, Hannover 1878.

Annales Iuvavenses maximi, MGH SS XXX, 2, ed. H. Bresslau, Leipzig 1934.

Annales Quedlinburgenses, MGH SS III, ed. G.H. Pertz, Hannover 1839.

Annales Weissemburgenses, MGH SS III, ed. G.H. Pertz, Hannover 1839.

Continuator Reginonis Trevirensis, MGH SS I, ed. G.H. Pertz, Stuttgart 1976.

Flodoardi annales, MGH SS III, ed. G.H. Pertz, Hannover 1839.

Gerhardi vita sancti Oudalrici episcopi Augustani, MGH SS IV, ed. G. Waitz, Hannover 1841.

Herimanni Augiensis chronicon, MGH SS V, ed. G.H. Pertz, Hannover 1985.

Hrotsvitha, Gesta Ottonis, [w:] Hrotsvithae opera, ScRG XXXIV, ed. P. von Winterfeld, Berlin 1902.

Liutprand, Antapodosis, [w:] Liutprandiopera, ScRG XLI, ed. J. Becker, Hannover-Leipzig 1915.

MGH Diplomatum regum et imperatorum Germaniae I, Hannover 1879-1884.

Richeri historiarum libri quatuor, MGH SS III, ed. G.H. Pertz, Hannover 1839.

Ruotgeri vita Brunonis archiepiscopi Coloniensis, ScRG SN X, ed. I. Ott, Weimar 1951.

Thietmari Merseburgensis episcopi chronicon, ScRG NS IX, ed. R. Holtzmann, Berlin 1935.

Widukindi monachi Corbeiensis rerum gestarum Saxonicarum libri tres, ScRG LX, ed.

P. Hirsch, Hannover 1935.

\section{Opracowania}

Althoff G., Breisach - ein Refugium für Rebellen im frühen Mittelalter?, [w:] Archäologie und Geschichte des ersten Jahrtausends in Südwestdeutchland, Sigmaringen 1990, s. 457-471.

Althoff G., Die Ottonen. Königsherrschaft ohne Staat, Stuttgart-Berlin-Köln 2000.

Althoff G., Zur Frage nach der Organisation der sächsischen coniurationes in der Ottonenzeit, „Frühmittelalterliche Studien” 1982, R. 16, s. 129-142.

Althoff G., Keller H., Heinrich I. und Otto der Grosse. Neubeginn aufkarolingischem Erbe, Bd. I, Göttingen-Zürich 1985. 
Becher M., Otton Wielki. Cesarz ipaństwo, przekł. B. Lipka, Oświęcim 2020.

Becher M., Rex, dux und gens. Untersuchungen zur Entstehung des sächsischen Herzogtums im 9. Und 10. Jahrhundert, Paderborn 1996.

Beumann H., Die Ottonen, Stuttgart-Berlin-Köln 2000.

Brühl C., Deutschland-Frankreich. Die Geburt zweier Völker, Köln-Wien 1995.

Dierauer J., Ruotger und der Aufstand von 953. Eine kritische Untersuchung, [w:] Untersuchungen zur mittleren Geschichte, hrsg. v. M. Büdinger, Bd. III, Abt. 1, Leipzig 1871, s. $3-50$.

Faussner H.C., Zum Regnum Bavariae Herzog Arnulfs (907-938), Wien 1984.

Glocker W., Die Verwandten der Ottonen und ibre Bedeutung in der Politik. Studien zur Familienpolitik und zur Genealogie des sächsischen Kaiserhauses, Köln-Wien 1989.

Goez W., Gestalten des Hochmittelalter. Personengeschichtliche Essays im allgemeinhistorischen Kontext: Bischof Ulrich von Augsburg (923-973), Darmstadt 1983.

Heselier G., Geschichte der Stadt Breisach am Rhein, Halbbd. 1: Von den Anfängen bis zum Jahr 1700, Breisach am Rhein 1969.

Keller H., Reichsstruktur und Herrschaftsauffassung in ottonisch-frühsalischer Zeit, „Frühmittelalterliche Studien” 1982, R. 16, s. 74-128.

Klewitz H.W., Das alemannische Herzogtum bis zur staufischen Epoche. Aufgaben und Probleme der Erforschung sieiner inneren Entwicklung und ihrer geistlichen Voraussetzungen, [w:] Oberrheiner, Schwaben, südalemannischen Räume und Kräfte im geistlichen Aufbau des deutschen Südwesen, hrsg. v. F. Maurer, Straßburg 1942, s. 79-110.

Köpke R., Dümmler E., Kaiser Otto der Große, Leipzig 1876.

Laudage J., Otto der Grosse (912-973). Eine Biographie, Regensburg 2001.

Leyser K.J., Herrschaft und Konflikt. König und Adel im ottonischen Sachsen, Göttingen 1984.

Lübke Ch., Regesten zur Geschichte der Slaven an Elbe und Oder (vom Jahr 900 an), t. 2, Berlin 1985.

Mittag A., Erzbischof Friedrich von Mainz und die Politik Ottos des Großen, Berlin 1895.

Norden W., Erzbischof Friedrich von Mainz und Otto der Grosse. Zur Entwicklung des deutschen Staatsgedankens in der Ottonenzeit, Berlin 1912.

Prinz F., Klerus und Krieg im früheren Mittelalter. Untersuchungen zur Rolle der Kirche beim Aufbau der Königsherrschaft, Stuttgart 1971.

Reindel K., Die bayerischen Luitpoldinger 893-989. Sammlung und Erläuterung der Quellen, München 1953.

Reindel K., Bayern vom Zeitalter der Karolinger bis zum Ende der Welfenherrschaft, [w:] Handbuch der bayerischen Geschichte, hrsg. v. M. Spindler, München 1981, s. 249-349.

Riezler S., Geschichte Baierns, Bd. I, Gotha 1878.

Schwenk P., Brun von Köln (925-965). Sein Leben, sein Werk und seine Bedeutung, Espelkamp 1995. 
Sochacki J., Formowanie się wczesnośredniowiecznego państwa niemieckiego w latach 919962, Słupsk 2014.

Sochacki J., Początki państw. Niemcy, Poznań 2016.

Strzelczyk J., Otton I Wielki, Poznań 2018.

Weitlauff M., Bischof Ulrich von Augsburg (923-973). Leben und Wirken eines Reichsbischof der ottonischen Zeit, [w:] Bischof Ulrich von Augsburg 890-973. Seine Zeit-sein Leben-seine Verehrung, hrsg. v. M. Weitlauff, Weißenhan 1993, s. 1-142.

Weller K., Geschichte des schwäbischen Stammes bis zum Untergang der Staufer, MünchenBerlin 1944.

Wolf G., Liudolfs „Gelage” in Saalfeld Weihnachten 951, „Zeitschrift für Rechtsgeschichte” 1985, R. 102, GA, s. 322-327.

Zotz T., Amicitia und Discordia. Zu einer Neuerscheinung über das Verhältnis von Königtum und Adel im frühottonischer Zeit, „Francia” 1989, R. 1, s. 169-175.

\title{
Jarosław Sochacki
}

\section{THE ROLE AND IMPORTANCE OF TOWNS IN REBELLIONS AGAINST OTTO I}

\begin{abstract}
Summary. During his reign Otto I had to face three serious revolts against his rule, which were initiated by his brothers Thankmar and Henry as well as by his son Liudolf. The aim of this paper is to show the role and importance of towns in these armed riots based upon the analysis of sources mainly of narrative character. The research has concluded that fortified outposts of any kind were of great importance as they allowed a major strengthening of one' position in particular region. With regard to Thankmar, such role had fallen to such places as Eresburg and Laër, whose surrender meant the effective end of rebellion. It was similar in other cases during Henry's rebellion, when fighting was concentrated around Merseburg, Chevermont and Scheidungen, and in the case of Liudolf for whom Regensburg finally became the central point of resistance. In the last case of rebellion an important role was also taken up by such towns as Mainz, Köln, Augsburg and Schwabmünchen in Swabia.
\end{abstract}

Keywords: Otto I, Thankmar, Henry, Liudolf, Eresburg, Laër, Merseburg, Chevermont, Scheidungen, Regensburg, Augsburg, Schwabmünchen 